\title{
JERUSALEM: CITY OF DREAMS, CITY OF SORROWS
}

More than ever before, urban historians tell us that global cities tend to look very much alike. For U.S. students. the“ look alike” perspective makes it more difficult to empathize with and to understand cultures and societies other than their own. The admittedly superficial similarities of global cities with U.S. ones leads to misunderstandings and confusion. The multiplicity of cybercafés, high-rise buildings, bars and discothèques, international hotels, restaurants, and boutique retailers in shopping malls and multiplex cinemas gives these global cities the appearances of familiarity. The ubiquity of schools, university campuses, signs, streetlights, and urban transportation systems can only add to an outsider’s “cultural and social blindness.” Prevailing U.S. learning goals that underscore American values of individualism, self-confidence, and material comfort are, more often than not,

obstacles for any quick study or understanding of world cultures and societies by visiting U.S. student and faculty. ${ }^{1}$

Therefore, international educators need to look for and find ways in which their students are able to look beyond the veneer of the modern global city through careful program planning and learning strategies that seek to affect the students in their "reading and learning” about these fertile centers of liberal learning. As the students become acquainted with the streets, neighborhoods, and urban centers of their global city, their understanding of its ways and habits is embellished and enriched by the walls, neighborhoods, institutions, and archaeological sites that might otherwise cause them their "cultural and social blindness."

Jerusalem is more than an intriguing global historical city. It is a classroom for liberal learning and international understanding. It had never, as far as we know, been a city of one language, one religion and one culture. Looking at the origins of Jerusalem's name indicates its international and multicultural nature. First known in Pharonic Egyptian texts as Urusalem (City/House of Salem or Peace) and then in the Judaic traditions as Yerusalem, it was subsequently named by the Islamic Arabic-speakers as the Bait al-Maqdis, or Al-Quds for short. The latter name remains in use throughout the Arab and Islamic world. While Israelis designate Jerusalem as its present capital, the Palestinians recognize it as their traditional capital. The following social and cultural history of Jerusalem intends to clarify what appears at first sight to be one Jerusalem, but which is in fact three Jerusalems, and to suggest strategies for understanding them 
As early as 3000 BC, the Old City was an organic entity focused on its religious and sacred nature becoming in time both a pilgrimage and market center. From the mid-19 ${ }^{\text {th }}$ century, Jerusalem began to grow out of its Old City into a New City until after the 1948 establishment of the Jewish State of Israel and the subsequent ceasefire agreements with Egypt, Jordan, Lebanon, and Syria in February 1949. The former British Mandate of Palestine was then divided into three parts among Israeli, Egyptian, and Jordan military forces. A divided Jerusalem was partitioned into an Israeli sector and a Jordanian sector separated by pillbox military posts and rolls of concertina barbed wire. Following the 1967 June War and the defeat of both Jordanian and Egyptian forces for the control of the West Bank and Gaza Strip portions of Mandate Palestine, three Jerusalems began to appear on the original site of the ancient and medieval Holy City.

The paper intends to introduce the U.S. international educator, faculty, and students to the past 500 years of Jerusalem's social and cultural history by focusing on 1. the geography and physical nature of the Holy City and its quarters (ahya'), 2. the social and economic growth up to 1948 of the Old (walled) City and the surrounding neighborhoods (harat) of the New (unwalled) City in terms of schools, public services and markets, and 3. the present cultural, social, and political presence of Israelis, and the Jewish colonial settlements, or neighborhoods encircling both the Old City and the new City of the $21^{\text {st }}$ century. Throughout the historical narrative of major events and persons that shaped Jerusalem and constructed its functions and settlement patterns, the international educator may wish to use the following suggested strategies to assist students in their study abroad learning of medieval and modern Jerusalem.

TEACHING STRATAGIES - Field exercises are helpful for students to grasp some of the complexities of presentday Jerusalem, and to understand a number of contradictory features of the Old and New cities. 1. Take the students to Jaffa Gate on the south side of the Old City and ask them to walk for twenty minutes out of the gate in any direction taking short but specific notes on the "European" nature of the New City. Then ask them to return to Jaffa Gate and walk in any direction within the Old City noting the "Middle Eastern"nature of the Old City. 2. Take time to discuss the students' lists of physical features that they have listed under the "European" heading and those they listed under the "Middle Eastern" heading. See if any have referred to peoples dress, behavior or walking styles under each heading. Discuss with them the various work places they observed under each heading, and ask the students to explain why certain items were under one heading and others under the other. Are the lists clearly representing the "European" versus "Middle Eastern" nature of their listed items? Or, are the students having second thoughts about the simplicity or overly generalized notions that they had before setting out on the field exercise? The learning strategy is to the get the students to challenge their own assumptions about what is meant by "European" versus "Middle Eastern" and to wonder how to be more insightful and analytical in what they had observed. A second strategy is to have the students walk through parts of the New City (for example, from the Damascus Gate to the Nablus Road or from the Jaffa Gate up the Jaffa Road and ask them to make brief but concise lists of "religious" or "political" or "cultural" features of the city that they walked past. 


\section{ISLAMIC AND ARAB JERUSALEM}

In AD 637, Commander Abu Ubaida accepted the surrender or sulh of Jerusalem to the Islamic Arab forces without preconditions. It seems that Jerusalem had no military or strategic importance, but it did have religious importance. $^{2}$ For the Muslims, the town was the Bait al-Maqdis, (Sacred House) due to the presence of the Haram al-Sharif or Noble Sanctuary which included the Rock to be built up fifty-eight years later as the Dome of the Rock (incorrectly known as the mosque of Omar) and the Al-Aqsa Mosque. The Caliph Umar did visit the city and the Haram al-Sharif a short time later thereby enhancing the importance of the sulh that guaranteed the safety of the people, their property, and their churches in return for a tax. In time, the Caliph Omar's visit and the promises of the sulh led to it being designated the "Covenant of Omar."

For the Christians, Jerusalem was sacred for having the first patriarch and the most venerated churches of Christendom, such as the Church of the Holy Sepluchre. From the $7^{\text {th }}$ to the $11^{\text {th }}$ centuries, the Bait al-Maqdis remained a walled pilgrimage site primarily with a semblance of a town and local market gathered around the churches and Haram al-Sharif. It was in the last decades of the $11^{\text {th }}$ century that a great turbulence occurred in the Arab East as well as in Europe. At noon on July 15 ${ }^{\text {th }}$, 1099, European crusaders entered the City after a month-long defense of the walls by the Muslim population. Storming through the city from Mount Zion and the Damascus Gates on the south and north sides of the City respectively, the Crusaders drove the inhabitants before them through the narrow streets. "An atrocious massacre followed with almost all the inhabitants of the city, men, women and children were killed in the streets, alleys, houses” and even in the al-Aqsa Mosque in the Haram al-Sharif with some 70,000 fatalities. ${ }^{3}$ Dignitaries and learned scholars were spared the massacre for purposes of ransom if such could be raised. Otherwise, even the Christian elites came to a disastrous end.

From the $12^{\text {th }}$ to the $16^{\text {th }}$ centuries, the Holy City was taken and retaken a number of times by successive Crusaders, and the walls were leveled and then rebuilt according to the whim of successive conquerors. Islamic heroes such as Salah-al-Din restored Jerusalem following his AD 1187 reconquest of the city including the neighboring shrines to past likenesses, and he built a number of Islamic colleges or madrasas. In time, forty-three colleges were founded in Jerusalem during what is known as the Ayyubid and Mamluk periods.

LEARNING STRATEGIES - Programs would do well to consider asking the students to complete one of the following learning strategies during their stay in Jerusalem: 1. keep a journal to be shared at weekly group 
meetings, 2. decide which social groups of teachers, shopkeepers, grocers, hair cutters, civil servants or professionals such as doctors, lawyers and engineers of Palestinians and Israelis to be interviewed with a tape recorder for a minimum of thirty minutes on at least three topics (their family, their formal education, and their present work and skills,), to be transcribed, handed out and discussed, 3. map a neighborhood by walking around with a notebook jotting down obvious landmarks, sizes of homes and varieties of occupants and then offering a brief social and cultural commentary on the "nature" of the neighborhood, and finally, 4. identify the seven hills of Jerusalem and their role in Jerusalem's long history.

\section{OTTOMAN JERUSALEM}

The year 1516 “was a memorable year for Jerusalem.” In August 1516, the triumphant Ottoman Turkish forces entered the city. Not unlike the earlier Islamic Arab caliph, the Sultan Selim I made a visit to the Holy City while on his way to Egypt. It was written that:

All the ulema and pious men went out to meet Selim Shah...They handed him the keys to the Aqsa Mosque and Dome of the Rock. He then made presents to all the notable people, exempted them from onerous taxes and confirmed them. ${ }^{4}$

As a holy city of Islam, Jerusalem enjoyed some of its finest days under Islamic Ottoman rule particularly during the reign of Sulaiman (1520-1566) when major reconstruction works were undertaken similar to the earlier $7^{\text {th }}$ and $13^{\text {th }}$ centuries. On Sulaiman's specific orders, an extensive restoration of the Dome of the Rock was completed. Though the Sulaiman restorations of windows, mosaics, and madrasas are well known, he is chiefly remembered for his building the City’s magnificent walls that stand to this day. Measuring two miles long and averaging forty-five feet in height, the walls have thirty-four towers and seven open gates most of which date from this restoration period beginning with the north Damascus or Bab al-Amud (Columns Gate), extending to the south Jaffa or Bab al-Khalil (Hebron Gate). The construction took five years to complete (AD 1536-40) and entailed enormous expenses in labor and materials. The sultan also turned his attention to the chronic water problem of the Holy City, spending large sums of money on canals, pools, fountains, and baths.

$16^{\text {th }}$ century Ottoman Jerusalem was a busy place economically speaking. There appeared to be five different types of industries and trade at the time: 1 . food processing industries such as fruit and oil processing, production of sesame and grain grinding, 2. textile and dye industries, 3. leather industries, 4. nine soap factories, and 5. iron and copper workshops. In addition, there were forty guilds or tawa'if ranging from professional guilds for physicians and architects to guilds for millers, cooks, spice dealers, and a rainbow of fees on visits to holy sites, lands, market taxes, adult poll and other taxes on Muslim population. In addition, a special tax was levied on the 
Christian and Jewish population as “protected people.” Therefore, a large portion of the city's revenue came from the fees paid by the pilgrims, merchants, and tourists. ${ }^{5}$

A $17^{\text {th }}$ century Ottoman visitor to Jerusalem noted that the population had reached 46,000 and that the city had 43,000 vineyards and its hills covered with olive trees. He further noted that the cities had seventeen Islamic schools, forty madrasas, and nearly seventy sufi orders along with six notable market inns or khans, six bathhouses and sixteen fountains. Finally, the Ottoman visitor wrote that there were more than two thousand shops in Jerusalem along with two Armenian and, three Greek orthodox churches, and two synagogues. Since all houses and buildings of Jerusalem were within the walls of Sultan Sulaiman, the control over the travelers and visitors to the City was primarily for security reasons. All persons including Muslims had to have permission to enter the gates of Jerusalem which were closed usually from sunset to sunrise.

TEACHING STRATEGIES - Three strategies may be used to understand Ottoman Jerusalem: 1. ask the students to identify the "Ottoman" features of the Old City in terms of its architecture, the object itself (a gate, fountain, building, neighborhood, or doorway) and the features' social and cultural functions within Ottoman Jerusalem, 2. have them explain the reasons for all the schools, bathhouses, merchant houses (khans) and sufi orders in Ottoman Jerusalem, and, 3. explain what values, ethics and civic engagements these institutions represent in the $16^{\text {th }}$ to $18^{\text {th }}$ centuries. Use group discussions to engage the students with each other in using comparative and contrastive analyses with other $16^{\text {th }}-18^{\text {th }}$ cc. Ottoman cities that they may have visited (Istanbul, Cairo, Aleppo, Damascus, or Beirut), or comparisons with US cities. Ask the students to name all the gates of the Old City and try to guess their meaning and social functions.. How important are their geographical positions around the city, are the religious sites or markets more important in the naming of the gates, and how do the gates relate to the neighborhoods in which they are found?

\section{PALESTINIAN JERUSALEM ${ }^{6}$}

The $19^{\text {th }}$ century was both a time of European expansion into Palestine and the Middle East, and of extensive domestic development in Jerusalem. In 1838, the first European diplomatic presence in Jerusalem was the establishment of the British Consulate that was soon followed by the Prussian, Sardinian, French, Austrian, Spanish, American and Russian consulates between 1842 and 1857. Consulates were soon followed by a religious-missionary "invasion” expressed through the founding of missionary schools in and around the Jerusalem, Ramallah, and Bethlehem area as well as in Nazareth, Haifa and Jaffa. Some of the leading European mission schools were established by the British Church Mission Society (CMS) and the Anglican Church (Jerusalem Girls' College, St.

George's School, The English School for Boys), by the Anglo-Prussian London Jews Society or CMJ (Bishop Gobat School for Boys and the Preparandi), by German secular and religious groups (the Deutsche Schule, the Schmidt's College for Girls, and the Talitha Kumi Girls School), by French missionaries (the Collège des Frères for Boys, the 
Collège de Père Ratisbonne for Boys, the Collège de Sainte Joseph for Girls, and the École de Sion for Girls), by the Italians monks (the Terra Sancta College for Boys and the Cardinal Ferrari Terra Sancta College for Boys), and by individuals or overseas organizations, such as the German orphanage (The Schneller Syrian Orphanage), the Lutheran Swedish Jerusalem Society (The Swedish School), the Jewish Evelina de Rothschild School for Girls, and the Alliance Israélite Universelle schools, and the American Colony School. Overall, between 1852 and 1948, there were forty-five foreign Christian schools and orphanages established in and outside of the Old City of Jerusalem.

The religious-political importance of Palestinian Jerusalem by the mid- $19^{\text {th }}$ century was further emphasized by the establishment of several key bishoprics and patriarchates beginning with the Anglo-Prussian Bishopric of 1841 and including the restoration of the Latin (Roman Catholic) Patriarchate, the arrival of the Greek Orthodox Patriarchate from Constantinople and the beginning of the Russian Orthodox Bishopric in the 1880s. By the 1860's, homes were being renovated, and new ones built inside the walls. Jewish residences sprang up on either side of the Jaffa road outside the walls while prominent and wealthy Palestine Muslim and Christians began to build new Arab neighborhoods to the north, west, and south of Jerusalem whose names survive to this day. $19^{\text {th }}$-century Palestinian neighborhoods, such as Rehavieh, Musrara, Mamillah, Qatamon, Talbiya, the Baq'a and Silwan to the west and south are Jewish neighborhoods today following the banishment of the Palestinians and their occupation by Jewish immigrants in the 1948 war while al-Mas'udiyya, Wadi al-Joz, Shaykh Jarrah, and Bab al-Zahira to the north, and Suwaneh, Abu Tor, al-Nabi Dawoud, and Ras al-Amud to the east remain Palestinian. These Muslim, Christian and Jewish neighborhoods soon rendered the Holy City's walls obsolete. By the 1870s, the gates remained open at night and during the Muslim Friday prayer. ${ }^{7}$

The Muslim, Christian and Jewish population in 1800 Jerusalem was estimated to be 8,750 with 4,000 Muslims, 2,750 Christians and 2,000 Jews. By 1850, however, the total Old City population had nearly doubled in size to 15,000 Jerusalemites (9,000 Muslims and Christians, and 6,000 Jews). From mid-century to the eve of World War One, both Old City and New Jerusalem more than quadrupled its population to 70,000 (25,000 Muslims and Christians and 45,000 Jews) with the Jewish representing the fastest growth. In 1882, the East European Jewish immigration to Palestine and to Jerusalem began in earnest in reaction to the rise of a series of Russian pogroms and anti-Jewish urban movements within the Russian and Austrian-Hungarian empires. Two 1880s Jewish colonies were established in Palestine in this period that remain well-known "pioneer landmarks.” For example, Rishon le-TZion now incorporated as a suburb of present-day Tel Aviv was established by the $19^{\text {th }}$-century Russian Hovevei Zion 
(Lovers of Zion) movement while Petah Tikva was settled west of Tel Aviv in Ottoman Palestine in 1883 following the draining of a number of malarial swamps and the financial assistance by a private foreign investor.

By the early 1900s, the annual influx from Christmas to Eastertide of 10,000 Russian pilgrims created an entirely new neighborhood just west of the Old City known as the al-Moskobiyya complete with pilgrim dormitories, kitchens and a Russian Orthodox church. The complex of buildings and the church survived the British Mandate period as the headquarters for the Palestine Police Force and, later on, became one of the New City's prisons under Israeli rule. At the same time, new Jewish neighborhoods sprouted up north and west of the Old City’s walls since the Jewish Quarter within the walls was almost entirely composed of Islamic endowed or awqaf lands. Thus, the new Jewish immigrants could only rent houses from their Muslim landlords. The only possibility in privately owning land and property was to buy land from outside and around Jerusalem which generally was considered freehold property and not Ottoman state or Islamic lands.

In addition to the pre-World War One influx of Jewish colonists to Palestine and to Jerusalem, various European and American Christian colonists were arriving in Jerusalem, such as the German Templars in the German Colony to the south of the city. Similar German and Austrian colonists were immigrating to Haifa, Jaffa and Sarona. A Greek colony was established to the southwest of the City, and an American religious colony just north of the Damascus Gate - both the present Greek Colony and American Colony Hotel remain witnesses to that European and American colonization process.

Between the 1880s and World War One, a network of roads and railroads built by French and German companies expedited communications between the Palestinian towns and villages along the coast and in the highlands thus improving year-round trade and pilgrimage contact with the highland towns of Jerusalem, Nablus and Jenin. The introduction of a telephone and telegraph network occurred in the same period. Jerusalem, in particular, became the leading provincial capital with increased privileged status in Ottoman eyes as Constantinople watched the foreign immigration into Palestine and, particularly to the pilgrimage-market city of Jerusalem with interest and concern. By the late- $19^{\text {th }}$ century, several leading Jerusalemite Muslim families had emerged as Palestinian administrative, religious, literati, and intellectual elites led by the Khalidis, Husaynis, and Nashashibis among others. Members of these families were among the Palestinian delegation to Constantinople's post- 1874 Parliament and were notables among the other leading Palestinian families from Nablus, Jaffa and Haifa in the Ottoman 
political parties of the time. The traditional rivalries among these landowning and powerful Palestinian families were only slightly lessened by their growing concerns over European, particularly Britain’s imperial interests in Palestine and the rise of various Zionist quests for a homeland.

The London announcement of the 2 November 1917 Balfour Declaration recognizing the Zionist goal of a “national homeland” in Palestine followed by the 1922 establishment of a British Mandate (colony) in Palestine soon created deepening divisions among the Jerusalemite Palestine’s leaders. Nonetheless, few of those families did not want nor foresee the "unsavory and sanguinary” consequences of World War One. ${ }^{8}$ The events of 1922 to 1942 were harbingers of the eventual 1947-1949 war, and the occupation and partition of Palestine and Jerusalem between Israel, Jordan, and Egypt.

LEARNING STRATEGIES - The program may require the students to find at least three former Christian mission schools of Jerusalem to 1. identify the buildings, their locations, and their present uses, 2. identify the neighborhood in which the schools are found, and 3. comment on or guess the schools' probable success or importance for Palestinians. Group meetings may want to discuss why so many missionary schools were present and were allowed to be built in Ottoman and British Colonial Jerusalem. The group may also want to ask who taught and attended such schools. The students may also want to speculate on the scarcity of Palestinian national schools in $20^{\text {th }}$-century Jerusalem at the time of the emerging Palestinian national movement. Finally, the students may want to discuss the nature and role of the exclusively Jewish Vaad Leumi (National Council) schools established in the early 1930s in British Colonial Palestine as well as the late date in establishing such schools.

\section{ISRAELI JERUSALEM}

From 1919 to 2009, Jerusalem has been the center of increasingly violent Muslim and Christian Palestinian reactions to the long-term Zionist goals (Israeli citizens and Israeli colonial settlers in the Occupied Territories) of home, land, and resources seizures within the boundaries of the British Mandate. In the aftermath of the 1947-1949 skirmishes and wars, Jerusalem's New and Old City Palestinian Muslim and Christian population figures went from $42 \%$ to $28 \%$ of Greater Jerusalem's total population. ${ }^{9}$ When compared with the pre-1880's $72 \%$ Palestinian population figure for Jerusalem, the present-day population percentages of that majority community are a very dramatic indicator of the demographic shift that has occurred in the Greater Jerusalem region over the past 120 years.

The 1947-49 war precipitated a massive Palestinian exodus and exile from their villages, fields and homes. Fleeing for their lives during day and nighttime firefights between the Israeli militias and commandos, and 
Palestinian and Arab resisters, the continuous raids on villages and homes successfully forced uprooting and indeed stampeding of 750,000 Palestinians from their homeland with thousands dead or wounded.

Today [Thursday, April 29 ${ }^{\text {th }}$, 1948], we have arranged with our school driver Abed Arafat to take us in the station wagon to Cairo tomorrow. Tata and Uncle Najeeb are planning to go down to the Old City. They have decided to spend one more night with us in Katamon in order to see us off in the morning. We are now the only family left in Katamon...We discussed the possibility of another strong attack upon Katamon...I still do not feel like leaving Jerusalem. $^{10}$

In the transformation of Jerusalem from a predominantly Palestinian Muslim and Christian Arab town to a predominantly Israeli Jewish European-American town following the 1947-49 and 1967 wars, the City itself lost much of its Palestinian personality as the Bait al-Maqdis. The process was neither a subtle nor a smooth one. Present-day Jerusalem is encircled, or as some prefer, embattled by the post-1967 hillside Israeli colonial neighborhood-settlements surrounding both the New and Old City. The building boom of neighborhoods, such as French Hill, Ramat Eshkol, Neve Yakov, Gilo, East Talpiot, Ramot and Pisgat Ze'ev along with the more recent Ramat Shlomo and Har Homa are regarded as illegal actions by the Palestinians, the UN and the European Union. ${ }^{11}$

The New City Jewish neighborhoods, hotels, and academic buildings were frequently built either on lands belonging to Christian institutions, or on Palestinian Muslim and Christian family-owned lands as in the cases of French Hill and Har Homa. ${ }^{12}$ The Old City, some suggest, has taken on characteristics no longer distinctive for their Palestinian, Ottoman, and Mamluk flavors, but has become a musty museum for tourists, travelers, and Israeli settlers/colonists. The following observations by an Israeli former deputy mayor of Jerusalem captures the devastating impact of the "ethnic cleansing” of the 1947-49 Palestinian villages and towns, many of whose residents fled to Jerusalem and its neighboring highland towns as wartime refugees:

Between 1987 and 1991, Palestinian geographer Ghazi Falah conducted a comprehensive survey of the remnants of the Arab landscape in Israel, classifying the remains of the abandoned towns and villages according to the extent of their destruction. His finds: two-thirds of the villages were completely wiped out, including some eighty that are unidentifiable because the land on which they stood has been plowed up, planted with trees, or excavated for commercial fish ponds. Other villages were totally demolished, but their outlines have been preserved thanks to prickly pear (sabra) cactus hedges, stone terraces, or fruit trees gone wild. In fifty-two of the approximately 400 abandoned Arab villages, there are visible signs that they were - or still are- inhabited by Jews. ${ }^{13}$

Today, Jerusalem in its rings and encirclements represents an embattled metropolitan region of Old, New, and Colonial cities more properly known as “Greater Jerusalem.”. It is a shadow of its former Arab Palestinian self. Seasonal holy days such as Yom Kippur, Ramadan and Christmas are still carried on regularly, and pilgrims, tourist 
groups, and predominantly Jewish immigrant groups arrive and leave in waves of colors and rainbows of passports.

The $21^{\text {st }}$-century construction of the $230+$ mile twenty-eight foot Wall and Towers known officially by Israel as the "Separation Fence” and, unofficially by Muslim and Christian Palestinians as the "Apartheid Wall” snakes it way

from Jenin in the northern Galilean plains to Jerusalem's urban limits on its way to the Negev Desert in the south. West Bank and Gazan and walled into the Occupied Territories.

Greater Jerusalem has thus been both a place of lifelong dreams, and a battlefield of torturous sorrows. The diminished Christian and Muslim communities in the Old and New City are not entirely absent from Jerusalem's market places, cinemas, and coffee house as daily conversations in Arabic, Armenian, Ottoman Turkish, and a variety of European languages dominate the streets, homes, cafes, and restaurants despite the Israeli habit of renaming quarters, streets, buildings, regions, and mountains. The emergence of thriving Orthodox Hasidic Jewish communities in the Old City, and in the exclusively Jewish colonial neighborhoods outside the wallsl only accentuates the strangeness of the present-day "Holy City" to many inhabitants and visitors alike.

TEACHING STRATEGIES - The program director may want to require the students to 1. identify the Israeli institutions and neighborhoods of Old and New Jerusalem both in terms of their architecture, location and importance to Jerusalem's Judaic identity, 2. ask the students to visit the Wailing Wall, Zion Square, the Yad Vashem (Holocaust Museum) and the Knesset (Parliament building) and to write an essay on what they saw and felt when visiting these sites, 3. walk through the Me'a Shearim neighborhood in West Jerusalem during a week day and again on Saturday, 4. write an essay on what they saw and felt during their visit, and 5. visit Hebrew University's Mt. Scopus campus with the students, introducing them to the student center, the library and bookstore identify the Western v. Middle Eastern characteristics and architecture along with the Truman Institute and Nancy Reagan Square.

\section{JERUSALEM AS A GLOBAL CENTER OF LEARNING}

Through the streets and quarters (ahya') of the Old City such as the Armenian Quarter and its $12^{\text {th }}$-century Armenian church with Convent, or the Church of the Redeemer in Muristan, or the Fourteen Stations along Via Dolorosa, the outsider is drawn into its warrens of street life both past and present. Similar to the labyrinth of calle and canals of maritime Venice, and the boundless bays of Istanbul's Gold Horn and the Bosphorus, the Old City invites the student to understand why a certain street name persists until today despite the Israeli name changes, and why certain quarters continue to prosper. When searching out Palestinian Mandate institutions such as the famous British-elite Palestine Government Arab College (PGAC),or Kuliyat al-Arabiyya, the U.S. students learn that its location is now an Israeli induction center for new Israeli immigrants renamed Kiryat Moriah located just south of 
Old City on the Jabal al-Mukabber or Mount of Evil Counsel. The students thus become aware of the historical narratives of dreams of new lives and sorrows for others on in the same location that Palestinian graduates of the PGAC, for example, still dream of a future University of Palestine. ${ }^{14}$ The power of Palestinian memories of lost opportunities maintains sorrows of occupation in place of dreams of a nation just as the present use of the GAC's 1927 dormitory by Israeli newcomers realizes the Zionist dreams of the Israeli immigrant in place of their past sorrows of failures and discomforture.

A walk along West Jerusalem’s Malchei Yisrael Street formerly called the Street of Prophets just blocks north of the present Jaffa Road will lead the students to the Hadassah headquarters housed in the former British Mandate’s Palestine Women's Training College (PWTC), a 1919 British-funded elite college for training Muslim and Christian women elementary school teachers. Hadassah was founded in the United States in 1912 to aid in the health and education of Jews in Palestine. Today, Hadassah continues in that former British college to raise funds to support its Zionist enterprises and dreams of better health care, education, youth-centered institutions and land usage in Israel at the expense of Palestinian dreams. ${ }^{15}$

Continuing westward along the same Malchei Yisrael Street, the US student will come upon a large walledin block of buildings with a gated entrance way. When standing in front of unusual looking main building topped with a leaning onion tower, the student will see a German inscription etched into the entrance stonework that reads Syrisches Waisenhaus or The Syrian Orphanage. ${ }^{16}$ Founded in 1860 by the German Lutheran missionary, Johann Ludwig Schneller began the orphanage that became Jerusalem’s first vocational school. Alternately known by Jerusalemites as the Schneller Orphanage, or the "Sneller School” it became famous for its educational programs for young boys and girls left homeless by wars, or poverty in Palestine and in the Fertile Crescent. The orphans were taught a range of practical skills in the school's barber shop, bakery, tailor and seamstress shops, and carpentry and electrician school.

During World War Two, British troops frequently confiscated area schools to set up barracks during wartime emergencies. The $90^{\text {th }}$ Battalion of the Royal Army Pay Corps of the British infantry occupied the "Schneller Barracks" in early 1948 when the Orphanage came under a surprise attack from the underground Jewish terrorist organization known as Irgun Zvai Leumi or Etzel. The nighttime attack during the early morning hours of March 12, 1948 left nine of the British soldiers seriously wounded with one dead, and several buildings destroyed. 
The Orphanage was soon abandoned by British troops in March 1948, and then occupied by Israeli troops from 1948 to $2008 .{ }^{17}$ Signs of the British colonial occupation and the subsequent conquests by Israeli forces scar the urban landscape of Jerusalem in many ways not unlike the World War Two occupations, confiscation of buildings and altering of streets in European capitals, such as Rome and Athens.

LEARNING STRATEGIES - The program director may want to the students to 1. visit the Old City's "four quarters" and note any outstanding features in each quarter that would identify it as "Jewish," or "Muslim," or "Christian," 2. write an essay on the global city features of Jerusalem in terms of its location, predominant institutions, peoples, and cultures, and 3. compare and contrast post-1948 Jerusalem with post-World War Two European and Asian global cities in terms of population transfers, wartime refugees, and post-war assistance and development plans, such as the Marshall Plan, U.S. Agency for International Development, and the World Bank programs.

For the study abroad student, Jerusalem's $20^{\text {th }}$-century past comes to life in the dark shadows of the Qattan or Cotton Market, and with the centuries old functional gateways into the walled city recalling its strategic commerce and religious importance in the late medieval and early modern era. The grand sweep of the Haram alSharif (Noble Sanctuary/Temple Mount) with the Dome of the Rock and the famous Al-Aqsa Mosque, the Jewish Wailing Wall, and the Church of the Holy Sepulchre crowded with Orthodox, Armenian, and Roman Catholic Christians will remind the student that Jerusalem is indeed a Holy City, and one of a number of global world religious centers. Istanbul has 3,000 mosques dominated by the magnificent Suleymaniye Mosque, Rome its numerous churches, the Vatican piazza and the elegant St. Peter's Basilica, and Paris the sky reaching gothic Cathedral of Notre Dame. So too, Jerusalem also maintains annual festivals of art, film and music recalling its past and present role as a world center of humanities similar to other Middle Eastern world centers, such as the music, art, book and film festivals in Cairo, Amman, and Damascus. As well, Jerusalem is filled with galleries of art, museums of ancient, medieval and modern treasures, and repertoire theatres. Its streets come alive with annual religious, ethnic, and secular feasts similar to other world centers such as New York, Bejing and Toronto.

Traditional artistic forms expressing universal human conditions dot the landscapes of world centers. Jerusalem is no exception, and can easily be seen as a site with a rich potential for study abroad learning.

\section{REFERENCES}

Antonius, George. The Arab Awakening: The Story of the Arab National Movement. NY: Simon Publications, (1939), 2001. 
Asali, Kamal J. Editor. Jerusalem in History NY: Olive Branch Press, 1990.

Ben-Arieh, Yehoshua. Jerusalem in the Nineteenth Century: The Old City. NY: St.Martin’s Press, 1986.

Ben-Arieh, Yehoshua. Jerusalem in the Nineteenth Century: The New City. NY: St. Martin’s Press, 1986.

Benvenisti, Meron. City of Stone: The Hidden History of Jerusalem. CA: University of California Press, 1966.

Sacred Landscape: The Buried History of the Holy Land Since 1948. CA: University of California Press, 2000.

Davis, Rochelle, “ Ottoman Jerusalem: The Growth of the City Outside the Walls.” In Jerusalem 1948: The Arab Neighbourhoods and Their fate in the War. Edited by Salim Tamari. Jerusalem: The Institute of Jerusalem Studies, 1999. Pp. 10-29.

. “Commemorating Education: Recollections of the Arab College in Jerusalem, 1918-1948."

Comparative Studies in South Asia, Africa, and the Middle East, 23, Nos. 1 \& 2 (2003), pp. 190-204.

Engle, John and Lilli Engle. "Neither International Nor Educative: Study Abroad in the Time of Globalization.” In Rockin' In Red Square, edited by Walter Grünzweig and Nana Rinehart. Germany: VG Bild-Kunst, 2002. Pp. 25-39.

Farwagi, Père Zacharie A. Dans et aux alentours de Jérusalem Pendant le mandate britannique (1922-1948). Leban: Imprimerie Catholique, 1994.

Jayyusi, Salma Khadra and Zafar Ishaq Ansari, Eds. My Jerusalem: Essays, Reminiscences, and Poems. MA: Olive Branch Press, 2005.

Jerusalem Quarterly multiple issues from volumes 1 to 42 published by the Institute of Jerusalem Studies in Ramallah, Occupied West Bank, Palestine.

Keith-Roach- Edward. Pasha of Jerusalem: Memoirs of a District Commissioner Under the British Mandate. UK: Radcliffe Press, 1994.

Khalidi, Rashid. Palestinian Identity: The Construction of Modern National Consciousness. NY: Columbia University Press, (1998), 2009. 
Moughrabi, Fouad and Munir Akash, Eds. The Open Vein of Jerusalem/Les Veines Ouvertes De Jerusalem. A Special Issue of Jusoor, Vol. 9/10 (1997/98. Bethesda, MD: Jusoor Books, 1997/1998.

Owen, Roger. Ed. Studies in the Economic and Social History of Palestine in the Nineteenth and Twentieth Centuries Carbondale, IL: The Southern Illinois University Press, 1982.

Pappe, Ilan. The Ethnic Cleansing of Palestine. UK: Oneworld Publications Limited, 2006.

Rogan, Eugene L. and Avi Shlaim, eds. The War for Palestine: Rewriting the History of 1948. UK: Cambridge University Press, 2001.

Rose, John H. Melkon. Armenians of Jerusalem: Memories of Life in Palestine. NY: St. Martin’s Press, 1993.

Sakakini, Hala. Jerusalem and I: A Personal Record. Amman, Jordan: The Economic Press, Co., 1987.

Schleifer, Abdullah. The Fall of Jerusalem. Second Printing. NY: Monthly Review Press, 1972.

Scholch, Alexander. “Jerusalem in the $19^{\text {th }}$ Century (1831-1917).” In Jerusalem in History. Edited by Kamal J. Asali. Brooklyn, NY: Olive Branch Press, 1990. Pp. 231-3.

Schulz, Helena Lindholm Helena. The Palestinian Diaspora: Formation of Identities and Politics of Homeland .Routledge, 2003.

Segev, Tom. One Palestine, Complete: Jews and Arabs Under the British Mandate. Henry Holt and Company, NY: 1999.

Sherman, A. J. Mandate Days: British Lives in Palestine, 1918-1948. Baltimore, MD: Johns Hopkins University Press, 1997.

Suleiman, Yasir. A War of Words: Language and Conflict in the Middle East. UK: Cambridge University Press, 2004.

Tamari, Salim. Ed. Jerusalem 1948: the Arab Neighbourhoods and Their Fate in the War. Jerusalem: The Institute of Jerusalem Studies, 1999.

Wasserstein, Bernard. Divided Jerusalem: The Struggle for the Holy City. Revised and Updated. London, UK: Profile Books, Ltd, 2002.

\section{ENDNOTES}

${ }^{1}$ The paper is written with U.S. students living and studying overseas specifically in mind. See an excellent discussion about the various learning obstacles facing U.S. study abroad students in John Engle and Lilli Engle, "Neither International nor Educative: Study Abroad in the Time of Globalization," in Rockin' In Red Square, edited by Walter Grünzweig and Nana Rinehart, (Bond, 2002), 26-7. 
${ }^{2}$ The paper is based on the scholarly writings, researches and memoirs of specialists with particular reference to the following: Kamal J. Asali, ed., Jerusalem in History (Brooklyn, NY, 1990), Meron Benvenisti, City of Stone: the Hidden History of Jerusalem, (Berkeley, CA, 1996), Hala Sakakini, Jerusalem and I, (Amman, Jordan, 1990), John H. Melkon Rose, Armenians of Jerusalem (New York, NY, 1993), Ilan Pappe, The Ethnic Cleansing of Palestine (Oxford, 2006), Abdulah Schleifer, The Fall of Jerusalem (New York, NY, 1972), Tom Segev, One Palestine, Complete (NY, 1999), A. J. Sherman, Mandate Days: British Lives in Palestine, 1918-1948 (Baltimore, MD, 1997), Salim Tamari, ed., Jerusalem 1948: The Arab Neighbourhoods and Their Fate in the War (Jerusalem, 1999), and Bernard Wasserstein, Divided Jerusalem: The Struggle for the Holy City (London, 2002).

${ }^{3}$ Mustafa A. Hiyari, “Crusader Jerusalem, 1099-1187," in Jerusalem in History, 130.

${ }^{4}$ Kamal J. Asali, “ Jerusalem Under the Ottomans, 1516-1831,” in Jerusalem in History, 200.

${ }^{5}$ Ibid, 204-6.

${ }^{6}$ The concept of "Palestinian Jerusalem" is a controversial one for Zionists and their supporters who deny the existence of Palestine, its lands, and its claims to Jerusalem. The concept is used in this paper to mean Jerusalem of the $19^{\text {th }}$ and $20^{\text {th }}$ centuries when a Palestinian consciousness had emerged particularly from the 1850s onward. For Palestinian leaders, there existed a Palestinian people, and their land, culture and history that could be identified as a distinct yet integral part of the larger Arab world.

${ }^{7}$ Rochelle Davis, "Ottoman Jerusalem: The Growth of the City Outside the Walls," in Jerusalem 1948: The Arab Neighbourhoods and Their Fate in the War, edited by Salim Tamari, (Jerusalem, 1999), 10-29, and Alexander Scholch, "Jerusalem in the $19^{\text {th }}$ Century, (1831-1917)," Jerusalem in History, edited by Kamal J. Asali, 231-3.

${ }^{8}$ See George Antonius, The Arab Awakening: The Story of the Arab National Movement (New York, NY, 2001).

9 See Rashid Khalidi, “The Palestinians and 1948: The Underlying Causes of Failure," in The War for Palestine, edited by Eugene L. Rogan and Avi Shlaim, pp. 14-15.

${ }^{10}$ Hala Sakakini, Jerusalem and I, 120.

${ }^{11}$ See the explanation of the illegal Jewish colonial neighborhoods usually called "settlements" in http://en.wikiopedia.org/wiki/Ring Neighborhoods Jerusalem.

${ }^{12}$ French Hill, founded as an illegal Israeli colonial settlement in 1969, had once belonged to the Catholic Monastery of St. Anne whose Catholic monks came mainly from France. http://en.wikipedia.org/wiki/French Hill. A BBC report suggests that French Hill was named after a British general. www.bbc.co.uk/dna/h2g2/42116784. Har Homa, an illegal Israeli colonial settlement, was established in 1997 on confiscated Christian Palestinian land known as Jabal Abu Ghneim adjacent to the Bethlehem suburb of Beit Sahour of Shepherds' Field fame (www.bbc.co.uk/2hi/middle east/7158072.stm). Portions of Hebrew University's Mount Scopus campus, and the Hyatt Jerusalem hotel were built on confiscated lands of five Jerusalem Palestinian Muslim families - see www.washington-report.org/backissues/072000/0007047

${ }^{13}$ Meron Benvenisti, Sacred Landscape, 169-70.

${ }^{14}$ A personal interview with six former graduates of the Palestine Government Arab College at the Amman, Jordan home of Dr. Abdulrahman Bushnaq, former student, Cambridge University/UK doctorate, and faculty member of GAC on September 14, 1995. See the excellent history of the GAC by Rochelle Davis, "Commemorating Education: 
Recollections of the Arab College in Jerusalem, 1918-1949, Comparative Studies in South Asia, Africa, and the Middle East, Vol. 23, Nos. 1 \& 2 (2003), 190-204.

${ }^{15}$ See Hadassah, the Women's Zionist Organization of America at http://www.hadassahinternational.org

${ }^{16}$ See Bernard Wasserstein, Divided Jerusalem, pp. 48 and 142.

${ }^{17}$ See the eyewitness account by Private Edward A. Worley of the $90^{\text {th }}$ Battalion, Royal Army Pay Corps in http://www.britains-smallwars.com/Palestein/Syrian-Orphanage.html.

Thomas M. Ricks, Ph.D., a founding Editor of Frontiers, and presently an independent scholar of Middle East social and cultural history, was the director of International Studies and Overseas Programs at Villanova University for fifteen years. Dr. Ricks is completing a social history of the Iranian city of Tabriz and the Amereican Presbyterian the Memorial School for Boys in that city. In 2009, he completed a study on Khalil Totah, a Palestinian Quaker educator, and his diaries. He is completing a study of Sarah Wright McDowell, an American Presbyterian missionary and social worker for half a century to Iran, and a social and cultural history of the Palestinian schools of Jerusalem, Ramallah and Bethlehem during the late-Ottoman and British Mandate periods. 